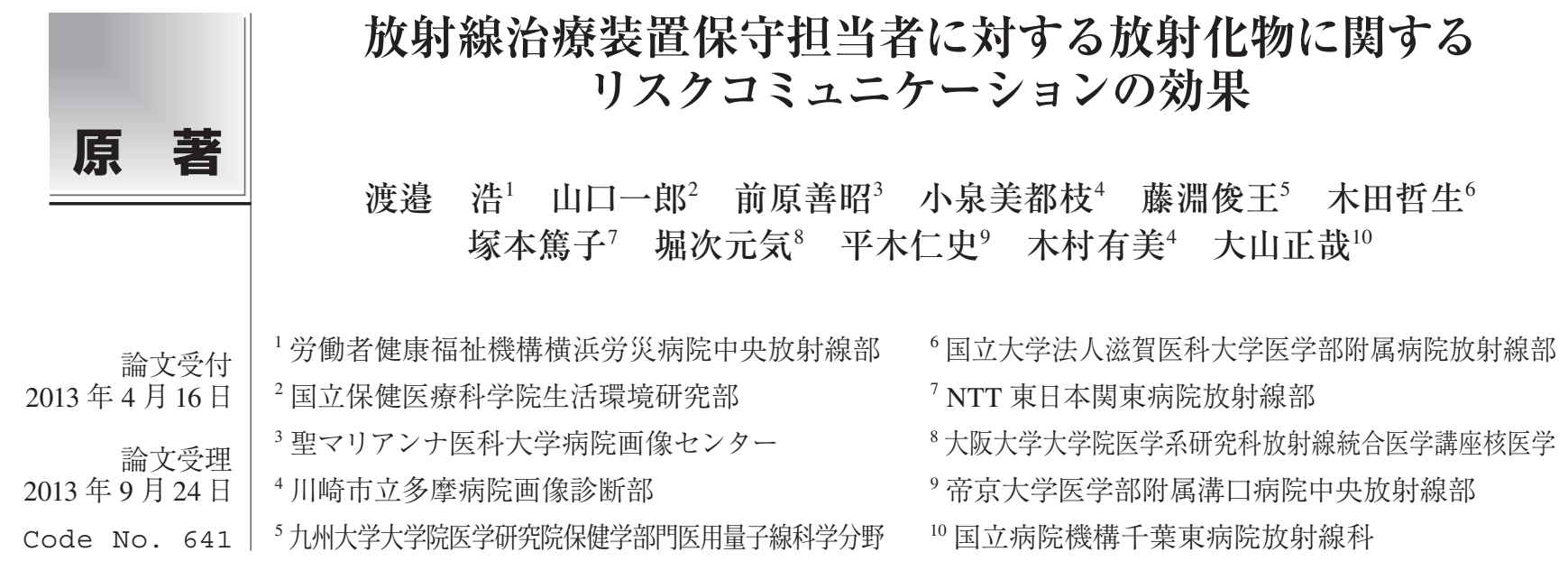

緒 言

放射線治療用直線加速装置(放射線治療装置)は光核 反応等によってターゲット等が放射化すること吕が知ら
れている，特に X 線の最大エネルギーが $10 \mathrm{MeV}$ を超 える装置では放射線計測でその存在が確認されること からも放射線管理上考慮が求められると考えられ，管

\title{
Evaluation of a Risk Communication Approach for Maintenance Staff Working with Induced Radioactivity in Medical Linear Accelerators
}

\author{
Hiroshi Watanabe, ${ }^{1 *}$ Ichiro Yamaguchi, ${ }^{2}$ Yoshiaki Maehara, ${ }^{3}$ Mitsue Koizumi, ${ }^{4}$ \\ Toshioh Fujibuchi, ${ }^{5}$ Tetsuo Kida, ${ }^{6}$ Atsuko Tsukamoto, ${ }^{7}$ Genki Horitsugi ${ }^{8}$ \\ Hitoshi Hiraki, ${ }^{9}$ Yumi Kimura, ${ }^{4}$ and Masaya Oyama ${ }^{10}$ \\ ${ }^{1}$ Department of Radiological Technology, Yokohama Rosai Hospital \\ ${ }^{2}$ Department of Environmental Health, National Institute of Public Health \\ ${ }^{3}$ Medical Imaging Center, St. Marianna University Hospital \\ ${ }^{4}$ Department of Diagnostic Imaging, Kawasaki Municipal Tama Hospital \\ ${ }^{5}$ Medical Quantum Science, Department of Health Physics, Faculty of Medial Sciences, Graduate School of Medical Sciences, Kyushu University \\ ${ }^{6}$ Department of Radiology Service, Shiga University of Medical Science Hospital \\ ${ }^{7}$ Department of Radiology, NTT Medical Center Tokyo \\ ${ }^{8}$ Department of Nuclear Medicine and Tracer Kinetics, Osaka University Graduate School of Medicine \\ ${ }^{9}$ Department of Radiological Technology, Teikyo University School of Medicine, University Hospital, Mizonokuchi \\ ${ }^{10}$ Department of Radiology, National Hospital Organization, Chiba East Hospital
}

Received April 16, 2013; Revision accepted September 24, 2013

Code No. 641

\section{Summary}

In order to promote consensus building on decommissioning operation rules for medical linear accelerators in Japan, we carried out a risk communication (RC) approach mainly providing knowledge for maintenance staff regarding induced radioactivity. In February 2012, we created a booklet (26 pages) to present an overview of the amended law, the mechanism and the distribution of induced radioactivity showing the actual radiation dose rate around a linear accelerator and actual exposure doses to staff. In addition, we co-sponsored a seminar for workers in this field organized by the Japan Medical Imaging and Radiological Systems Industries Association to explain the contents of this booklet, and answer questions regarding induced radioactivity of linear accelerators as an $\mathrm{RC}$ program. As a result, the understanding of staff regarding the regulations on maximum X-ray energy on linear accelerators $(P<0.05)$, and the outline of clearance systems $(P<0.01)$, were facilitated by RC. In addition, we found that about $70 \%$ of maintenance staff considered that the cooling time for decommissioning operation depended on the situation. Our RC approach suggests that consensus building should be used to make rules on decommissioning operations for linear medical accelerators.

Key words: risk communication, maintenance staff, induced radioactivity, medical linear accelerator, occupational exposure dose

*Proceeding author 
理区域に立ち入る医療従事者の被ばく線量等が報告さ れている2

本邦に扮ける放射線発生装置から発生した放射線に よる放射化物に関する規制は，これまで「放射線発生装 置使用施設に损ける放射化物の取扱いについて(通知)」 (平成 10 年 10 月 30 日科学技術庁原子力安全局放射線 安全課長)に基づき取り扱われてきたが，放射性同位元 素等による放射線障害の防止に関する法律(障防法)で は法令上の規定が存在せず，その取り扱いが課題と なっていた。このため, 包括的な放射化物規制とクリア ランス制度等を取り入れた改正障防法が平成 22 年 5 月 10 日に公布, 平成 24 年 4 月 1 日に施行された。

放射線治療装置の放射化物に対する規制は国際電気 標準会議(International Electrotechnical Commission: IEC) の規定 ${ }^{9}$ に存在するもののクリアランスレベルを援用す る安全側の規制は世界的にも初めてであり，関係学会 等が連携して対応するためにクリアランスおよび放射化 物に関する医療関係学会等団体合同ワーキンググルー プ(合同 working group: WG) が編成された ${ }^{10,11)}$. 合同 WG は，放射線治療に重大な障害を及ぼさない合理的 な法整備のために放射化物の核種，範囲，放射能濃度 および線量率等のエビデンス ${ }^{12 \sim 15)}$ を明らかにした。 ま た，本論文執筆時点において医療現場の管理方策をま とめた学会標準のドラフト版が公益社団法人日本放射 線技術学会(Japanese Society of Radiological Technology: JSRT)等の関連団体のホームページに公開された。した がって, 今後各医療機関はこの改正障防法ならびに学 会標準等に基づいて放射線治療装置の保守や装置更新 を行う必要がある ${ }^{16)}$.さらに, 適切に放射化物の管理を 行うためには，放射線治療装置の取り扱いや管理を行 う医療関係者だけでなく，保守等を行う放射線治療装 置メーカ関係者にも改正障防法や学会標準の内容を周 知する必要がある。

ここでもう一つ課題となるのは, 放射線治療装置更 新時において放射化物を減衰させるための期間をどの 程度確保するかである，放射線治療装置のターゲット 等の放射化の範囲, 照射停止後の放射能㧍よび線量 率が明確になったことによって, 日本画像医療システ ム工業会 (Japanese Medical Imaging and Radiological Systems Industries Association: JIRA)では, 照射停止か ら解体開始までの期間を十分に確保し放射化物の放射 能を減衰させてから更新作業を行いたい意向がある.

一方, 医療機関では放射線治療を行う患者が増加して いる現状があるため, できるだけ装置の稼働停止期間 を短くしたいと考えている，そのためには更新する旧放 射線治療装置の照射停止から解体までの期間をできる
だけ短くする必要がある。放射化した部品を近距離で 取り扱うのは放射線治療装置の運転, 点検, 修理等の 保守や据え付けあるいは解体を行う作業者(保守担当 者である.

そこでわれわれは，医療機関と放射線治療装置メ一 カ間の相互理解に基づいた装置解体作業ルールの合意 形成ひいては放射線治療の健全な発展を目指し, 放射 線治療装置の保守担当者に対するリスクコミュニケー ション(risk communication: RC)を行ったのでその結果 を報告する。

\section{1. 方 法}

\section{1-1 対 象}

対象は, 本邦の放射線治療装置の保守担当者とし た。 な扮，対象者の選定は，JIRAに依頼し，JIRA 放射 化物担当責任者から各メーカ担当責任者宛に依頼を行 い,メーカ担当責任者が自社の保守担当者を選定した.

\section{1-2 第一次調査票の配布, 回収}

平成 23 年 10 月 18 日, JIRA 放射化物担当責任者か ら各メーカ担当責任者宛に第一次調査票を送付すると ともに保守担当者への配布を依頼した，回収期間は平 成 23 年 11 月 1 日から同年 11 月 21 日までとした。 な お, メーカは本邦で放射線治療装置の保守を実施して いる株式会社バリアンメディカルシステムズ, エレクタ 株式会社, 株式会社日立メディコ, シーメンス・ジャパ ン株式会社㧍よび東芝メディカルシステムズ株式会社 の 5 社である。

なお, 調查票では, 業務内容, 医療機関からの作業 上の放射線安全に関する説明の必要性，業務での放射 線被ばくに対する不安・リスク認知, 作業前の減衰の必 要性，カテゴリ区分の合理性㧍よびクリアランス制度へ の認知を尋ねた。

\section{1-3 リスクコミュニケーション}

保守担当者に対する RCを行うため, A5 判 26 ペー ジの解説資料(以下，ブックレット)を作成し，平成 24 年 2 月 1 日, JIRAを介して保守担当者に配布した。 ま た，平成 24 年 2 月 7 日に開催された JIRA 主催の放射 線治療用直線加速装置の利用に伴う放射化物の管理と 処分の学会標準(案) と題された講習会(以下, 講習会) に参加した各メーカ担当者に改正障防法の概要と具体 的な対応方法について講義を行うとともに質疑に回答し た、ブックレットと講習会の概要を下記に示す。ただ し，ブックレットについては実際の目次ではなく RCの 内容に合わせて記している. 
Table 1 Relationship between type of job and timing of risk communication

\begin{tabular}{lcc}
\hline \hline \multirow{2}{*}{ Type of job } & $\begin{array}{c}\text { Ratio at each timing of inquiry } \\
\text { comparing the risk } \\
\text { communication program (\%) }\end{array}$ \\
\cline { 2 - 3 } Operation and checking of accelerator & Before & After \\
Installation and decommissioning of accelerator & 70 & 67 \\
Constructing a building & 47 & 46 \\
Assembling equipment and accessories & 14 & 4 \\
Management of waste disposal & 7 & 9 \\
Radiation measurement & 3 & 5 \\
Others & 5 & 6 \\
\hline
\end{tabular}

*The type of job was not changed during this risk communication.

1)ブックレット

(1) 放射線による人体影響 : 4 ページ

(2) 実際の保守担当者の被ばく線量 : 1 ページ

(3) 放射化の原理, 部品および線量率：6ページ

(4) 放射化物を処理するための作業手順および方法 : 2 ページ

(5) 改正法の目的と概要 : 2 ページ

(6) クリアランス制度 : 3 ページ

(7) 放射線の基礎知識 : 4 ページ

(8) ブックレットの目的およびその他：4 ページ

2)講習会

(1)クリアランス制度導入に伴う改正放射線障害防止法 施行の概要 : 25 分

(2)医療機関における放射線治療用直線加速装置の 利用に伴う放射化物の管理と処分に関する学会標 準(案)：70 分

\section{1-4 第二次調査票の配布, 回収}

平成 24 年 3 月 1 日, JIRA を介して第二次調査票の 配布を行い, 同年3月19日から31日までの期間, JIRAを介して回答を回収した。

\section{1-5 統計的検定と倫理}

第一次調査票と第二次調査票は放射化物に関する理 解について同一の質問を行い, その結果を Statcel2 (オーエムエス出版発刊, 柳井久江著) ${ }^{17)}$ および $\mathrm{R}$ version 2.14.1 ${ }^{18)}$ を用いて分割表に集計したカテゴリカル データに対してはカイ二乗分布を用いた独立性検定 (ピ アソンのカイ二乗検定), 順序尺度が用いられた項目で の比較はマンホイットニー検定を行い, $P<0.05$ 以下を 統計的に有意であると判断した.

また，本研究は日本放射線技術学会平成 22 年度お
よび平成 23 年度学術調査「放射性廃棄物のリスクコ ミュニケーション等に関する研究」班の活動結果報告で あり，アンケート調査および結果の取り扱いに関しては 研究計画の分担責任者であった班員が所属する川崎市 立多摩病院(指定管理者 学校法人聖マリアンナ医科 大学) 倫理委員会の事前承認に受けて行った(承認番 号：第多 110 号, 2011 年 7 月 8 日付).

\section{2. 結 果}

\section{2-1 調査票回収率}

$\mathrm{RC}$ 前の調査票の配布者数 135 名, 回答数 81 名で回 答率は $60 \%$ であった。 RC 後の調査票の配布者数は 137 名, 回答数 72 名で回答率は $53 \%$ であった。

なお，本論文では調査結果のうち主たる設問への回 答および減衰期間の設定等の医療機関と放射線治療装 置メーカによる合意形成に特に必要と考えられる結果を 示す.

\section{2-2 業務内容}

$\mathrm{RC}$ 前・後の回答者の業務内容に関する調査結果を Table 1 に示す(複数回答可). 放射線治療装置の運転. 点検，据え付け・解体が RC 前でそれぞれ 70\%，67\%， $\mathrm{RC}$ 後でそれぞれ67，46\%であった。 なお，解体作業 以外でも放射化物を扱う可能性があることから解体作 業に従事しない保守担当者からの回答も解析の対象に 加えた。

\section{2-3 放射線安全に関する説明}

医療機関から放射線安全に関して説明が必要である かの設問に対する結果を Fig. 1 示す。「必要である」との 回答は RC 前・後でそれぞれ 65\%,60\%で変化は認めら れなかった。 


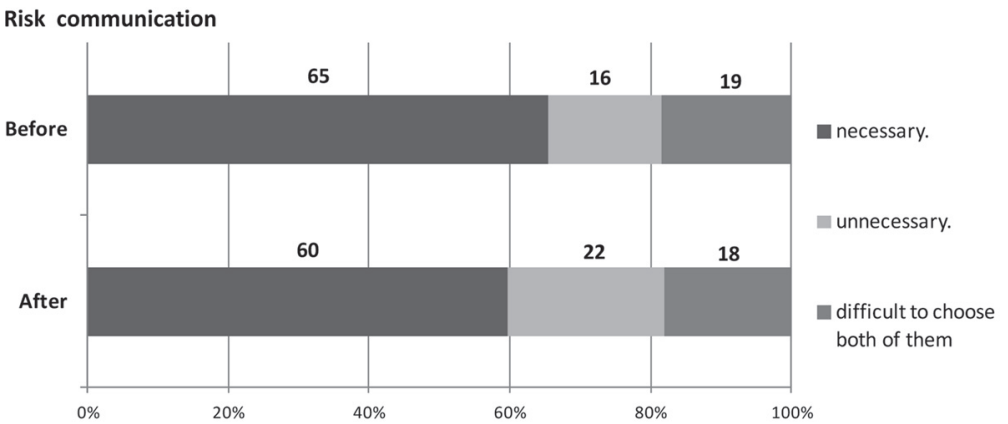

Fig. 1 Should the hospital provide safety information and instructions?

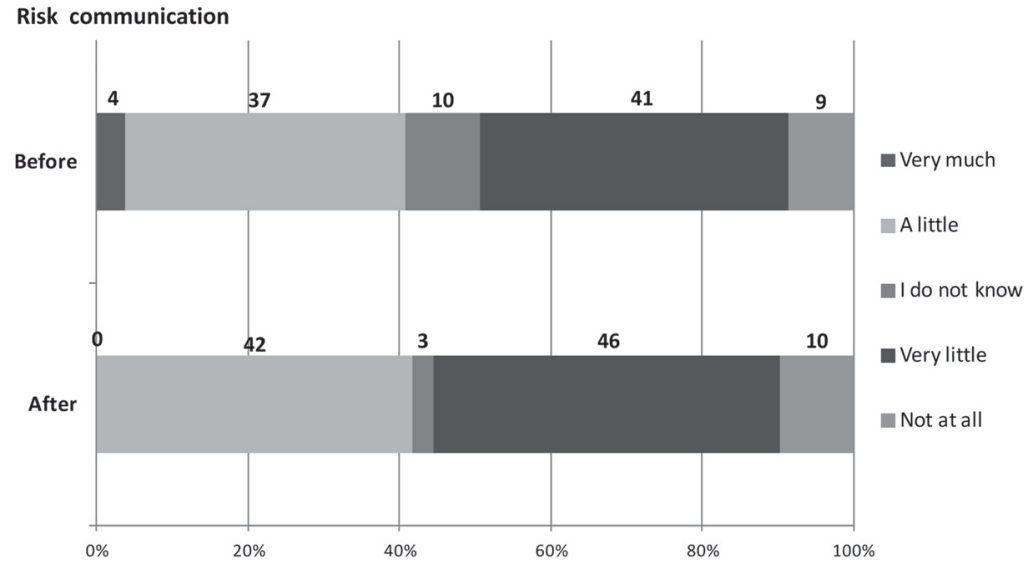

Fig. 2 Do you worry about radiation in controlled areas?

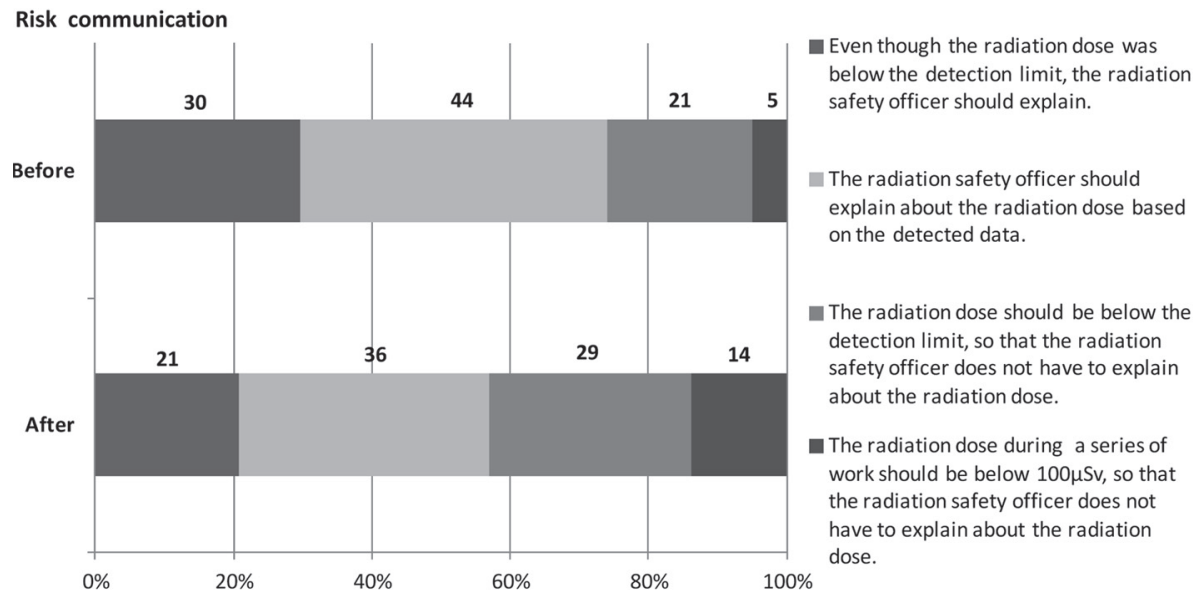

Fig. 3 Do you need a detailed explanation about the exposure dose and health effects?

\section{2-4＼cjkstart業務での放射線被ばくに対する不安}

放射線管理区域における作業での放射線被ばくに不 安を感じるかの設問に対する結果を Fig. 2 に示す。 RC 前・後で「非常に不安」と「多少不安あり」の合計はそれぞ れ 41\%，42\%で不安は減少しなかった。

\section{2-5 被ばくした線量と人体への影響に対する詳しい} 説明

被ばくした線量と人体への影響について詳しい説明
が必要かを尋ねた結果を Fig. 3 に示す。「被ばく線量が 検出限界以下でも必要である」は $30 \%$ から $21 \%$,「検出 された被ばく線量に応じた説明が必要である」は44\%か ら 36\%,「被ばく線量が検出限界以下なので不要であ る」は $21 \%$ から 29\%，「一連の作業あたり $100 \mu \mathrm{Sv}$ 未満 の被ばくなので不要である」は 5\%から $14 \%$ となった が，検定の多重性を考慮すると有意差はなかった $(P=0.10)$. 


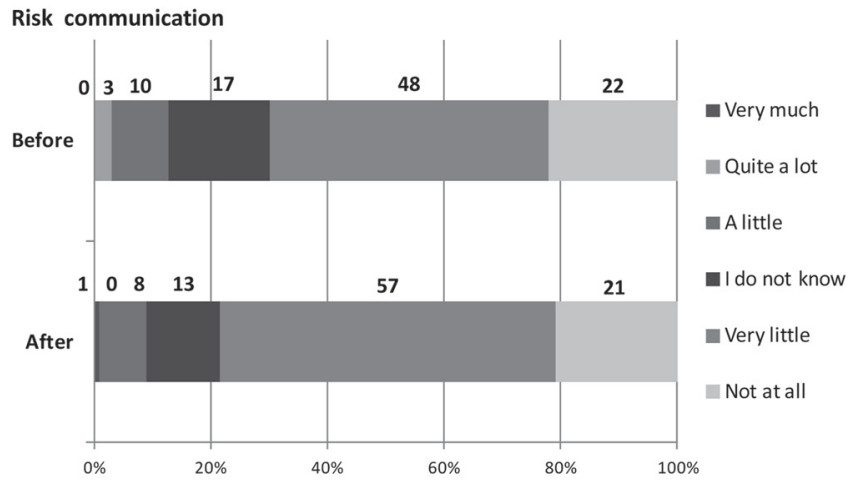

Fig. 4 Do you receive health effects from radiation during your work?

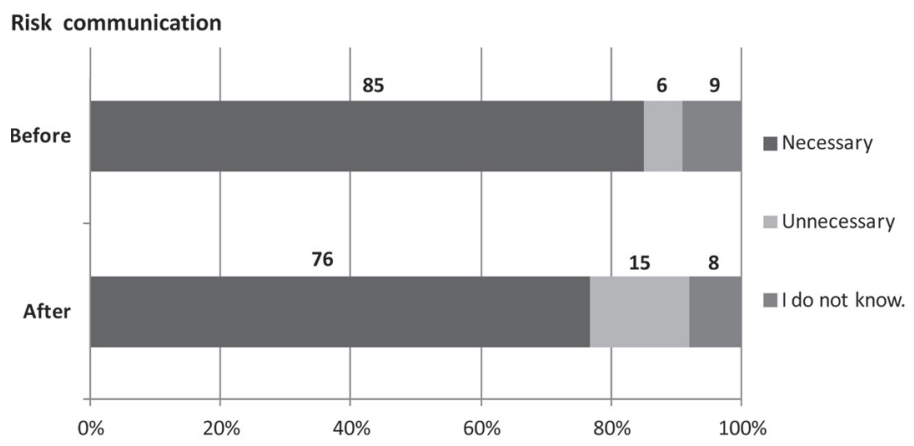

Fig. 5 Is it necessary to have induced radioactivity decay before you begin work?

\section{2-6人体への影響}

担当者自身が被ばくした線量が人体にどのくらい影 響を及ぼすかを尋ねた結果を Fig. 4 に示す， RC 後の 「ほとんど影響がない」と「まったく影響がない」の回答の 合計は $78 \%$ であったが, $\mathrm{RC}$ 前と比較すると人体への 影響がないと考える傾向に有意差はなかった $(P=0.62)$.

\section{2-7 減衰の必要性}

放射化物による放射線被ばくを避けるために照射終 了後, 放射能が減衰するまで一定時間が経ってから保 守や解体作業を行うことが必要であるかを尋ねた設問 の結果を Fig. 5 に示す.「減衰は不要」の回答は $6.2 \%$ か ら $15 \%$ になったが検定の多重性を考慮すると有意差は なかった $(P=0.18)$.

\section{2-8 減衰期間等}

放射化物による放射線被ばくを避けるために照射終 了後放射化物が減衰するまで一定時間が経ってから保 守や解体作業を行うことが必要であるかを尋ねた設問 において「減衰が必要である」と回答した担当者(第一次 調査 69 名, 第二次調查 55 名)に必要な期間等を尋ねた 結果を Table 2 に示す. なお, 回答は Table 2 に挙げた 項目すべてを選択肢として示して回答を求めた，ただ し,「その他」の回答はすべてX 線の最大エネルギー等
の状況に応じた期間とすべきと記述してあったため, そ の旨の回答に差し替えた。具体的期間を回答した担当 者は $33 \%$ から $22 \%$ になり, 物理的な機序, 測定デー夕 あるいは X 線の最大エネルギー等の状況に応じて考え るべきという回答が $59 \%$ から $73 \%$ になった。ただし， 個々の回答を含め $\mathrm{RC}$ 前後で変化の有意差はなかった $(P=0.15)$.

\section{2-9カテゴリ区分の合理性}

改正障防法では, $\mathrm{X}$ 線の最大エネルギー別にカテゴ リ分けをしており，「6 MeV 以下」は放射化を考慮しなく てよい, 「6 MeV を超えて $10 \mathrm{MeV}$ 以下」は, ターゲット などのヘッド内の一部部品のみ放射化物として規制対 象とする，「10 MeV を超える」は，医療機関が自ら放射 化の範囲を評価し，解体時の取扱方法を明記したうえ で個別に申請を行う，としており，このカテゴリ分けを 合理的であると思うかを尋ねた結果を Fig. 6 に示す. 「合理的である」は $46 \%$ から $65 \%$ に増加した $(P=0.02)$.

このカテゴリ分けでは「 $6 \mathrm{MeV}$ を超えて $10 \mathrm{MeV}$ 以 下」の放射線治療装置を解体する場合, ターゲット等の 取り外しなど, 多くの部品を現場で解体し, ヘッド内の 一部部品を保管・廃棄する必要がある. 現場での解体作 業を行うに当たって不安(心配)を感じるかを尋ねた結果 を Fig. 7 に示す。「非常に不安あり」または「多少不安」 
Table 2 How long should the decay period be?

\begin{tabular}{|c|c|c|c|c|c|}
\hline \multirow{2}{*}{\multicolumn{2}{|c|}{ Decay periods or other options }} & \multicolumn{4}{|c|}{$\begin{array}{l}\text { Ratio at each timing of inquiry comparing } \\
\text { the risk communication program }(\%)\end{array}$} \\
\hline & & \multicolumn{2}{|c|}{ Before } & \multicolumn{2}{|c|}{ After } \\
\hline \multirow{8}{*}{$\begin{array}{l}\text { Specific } \\
\text { periods }\end{array}$} & 30 minutes & 7 & & 4 & \\
\hline & 1 hour & 4 & & 0 & \\
\hline & 1 day & 3 & & 2 & \\
\hline & 3 days & 1 & 33 & 2 & 22 \\
\hline & 1 week & 7 & & 7 & \\
\hline & 2 weeks & 3 & & 5 & \\
\hline & 1 month & 3 & & 2 & \\
\hline & At least 1 month & 4 & & 0 & \\
\hline \multirow{3}{*}{ It depends } & on the physical mechanism & 23 & & 24 & \\
\hline & on the results of each measurement & 32 & 59 & 40 & 73 \\
\hline & on the maximum X-ray energy, etc. & 4 & & 9 & \\
\hline \multirow[t]{2}{*}{ I do not kno } & & 7 & 7 & 6 & 6 \\
\hline & Total & 100 & 100 & 100 & 100 \\
\hline
\end{tabular}

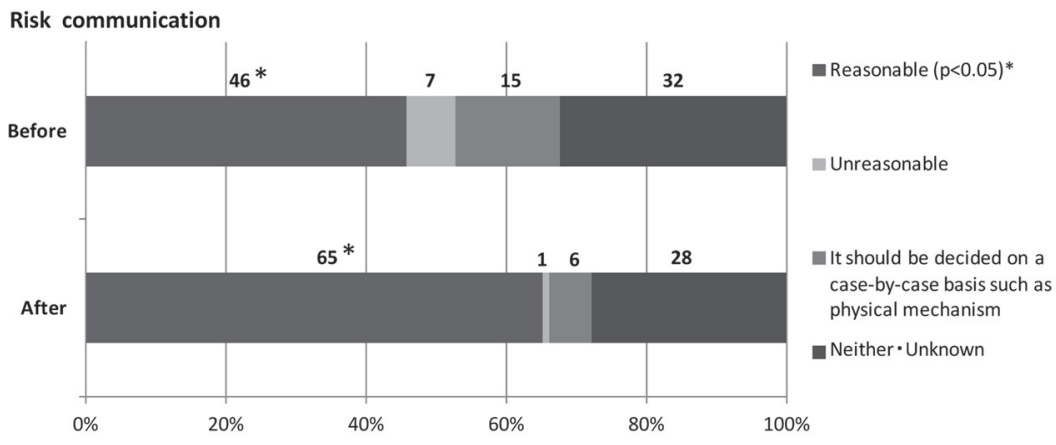

Fig. 6 Is it reasonable to classify based on the maximum energy of X-rays?

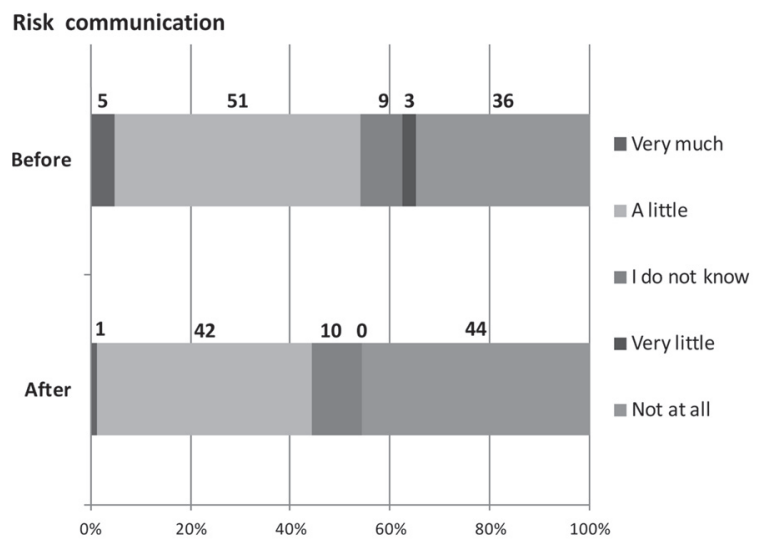

Fig. 7 Do you worry about the work of decommissioning the medical linear accelerator?

の回答割合は $56 \%$ から $43 \%$ となったが有意差はなかっ た $(P=0.19)$.

\section{2-10 クリアランス制度}

クリアランス制度の理解度を尋ねた設問の結果を Fig. 8 に示す。クリアランス制度を「知らない」という回 答は RC 前後で $62 \%$ から $28 \%$ に減少した $(P<0.01)$.

\section{3. 考 察}

\section{3-1 RC の効果と課題}

RC を実践するうえで，対象者の理解を進めるために はわかりやすい資料を作成することが重要となる。われ われがブックレットおよび講習会等によって実施した $\mathrm{RC}$ にて X 線の最大エネルギー別のカテゴリ分けの合 理性 $(P<0.05)$ およびクリアランス制度 $(P<0.01)$ の理解が 


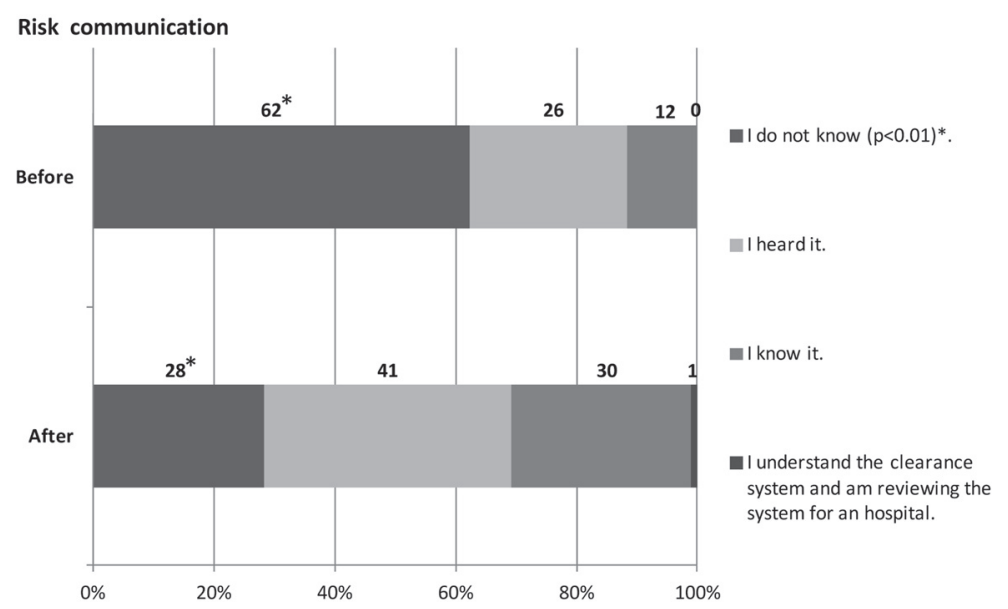

Fig. 8 Do you know the clearance system?

進んだことが示された(i)。また，これによってブック レットおよび講習会の有効性が明らかになった。

ブックレットのページ数と講習会の時間数を RC のボ リューム指標と考えて理解度の变化を見ると, 医療機関 から放射線安全に関しての説明の必要性, 放射線管理 区域に㧍ける作業での被ばくの不安ならびに「6 $\mathrm{MeV}$ を 超えて $10 \mathrm{MeV}$ 以下」の放射線治療装置を解体する場合 の不安は, $\mathrm{X}$ 線の最大エネルギー別のカテゴリ分けの 合理性掞よびクリアランス制度とほぼ同様のページ数あ るいは時間数であるにもかかわらず改善しなかった，被 ばく影響を含む放射線に対する不安は短期間の RCで は改善することが容易ではないことが確認された。これ によって，知識の向上を図る教育的な側面をもつ RC は ブックレットや講習会等の情報提供によって比較的容 易に進むものの被ばく不安などの心理的変化は容易に は進まないことが確認できた(ii).

医療機関から放射線安全に関しての説明が必要であ るとの回答は RC 前・後でそれぞれ $63 \% ， 60 \%$ で不変で あった。国際的な指針 ${ }^{19 \sim 21}$ は共通して，「雇用主は作業 者の防護に主な責任がある。しかし，その線源に責任 のある免許所有者(もし雇用主と同一でなければ)も，作 業者の放射線防護に対し責任がある.」としており，放 射線治療装置メーカと医療機関はともに保守担当者の 放射線防護に責任が生じている。したがって，今後も 医療機関と放射線治療装置メーカが保守担当者に対す る放射線防護の責務を果たす必要がある.

\section{3-2 減衰期間等の合意形成に向けた検討と課題}

今回の法整備の重要な目的の一つである放射化物の 規制に関して, ブックレットに $6 \mathrm{MeV}$ 以下では光核反 応のしきい值から放射化を考慮する必要がないことを
示し，また， $6 \mathrm{MeV}$ を超える放射線治療装置では規制 対象になった部品があり，6 $\mathrm{MeV}$ を超えて $10 \mathrm{MeV}$ 以 下と $10 \mathrm{MeV}$ を超える装置では規制対象範囲が異なる ことを示した。ささらに, $10 \mathrm{MeV}$ 以下の装置では 1 カ月 あたりの被ばく線量は個人モニ夕用の線量計の検出限 界 $(100 \mu \mathrm{Sv} /$ 月)を超えず，装置の解体あたりの線量は ポケット線量計の検出限界 $(1 \mu \mathrm{Sv} /$ 回 $)$ を超えないこと （Table 3）をJIRA の協力を得てブックレットに掲載し た。これによって改正障防法に打けるX 線の最大工ネ ルギー別のカテゴリ分けの合理性とともに放射化物に 対する理解が進んだことが示唆された(iii).

担当者自身が被ばくした線量が人体にどのくらい影 響を及ぼすかを尋ねた結果に扔いて， RC 後には保守担 当者の $78 \%$ \%「ほとんど影響がない」か「まったく影響が ないり考えていた(iv)。しかし，「被ばく線量が検出限 界以下でも必要である」と「検出された被ばく線量に応 じた説明が必要である」の合計が $57 \%$ で過半数を超え

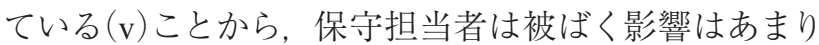
ないと打抢よそ理解しているが被ばく不安が完全に払 拭できて捛らず，受けたあるいは検出限界以下の線量 による人体影響について説明が必要と考えて抢り，保 守担当者が不安を完全に払拭できていない課題の特性 を捉えるとともに放射線の人体影響をどう伝えるかが課 題であることが確認された。したがって，低線量被ばく による人体影響について教育訓練の工夫・充実を図る必 要があると考える(vi)。

減衰期間については，物理的な機序，測定線量(率) あるいは X 線の最大エネルギー等に応じて設定すべき という回答が 59\%から 73\%になり変化は有意ではない ものの多くの担当者が減衰期間を一律に決めるのでは なく放射化の状況に応じて決めるべきと考えていること 
Table 3 Actual exposure dose of maintenance staff for medical linear accelerators

\begin{tabular}{|c|c|c|c|c|c|c|c|}
\hline $\begin{array}{l}\text { Accelerator } \\
\text { company }\end{array}$ & $\begin{array}{l}\text { Fiscal } \\
\text { year }\end{array}$ & $\begin{array}{c}\text { X-ray } \\
\text { maximum } \\
\text { energy }(\mathrm{MeV})\end{array}$ & $\begin{array}{l}\text { Number of } \\
\text { measured } \\
\text { staff }\end{array}$ & Dosimeter $^{* 2}$ & $\begin{array}{l}\text { Number of } \\
\text { dismantled } \\
\text { accelerators }\end{array}$ & $\begin{array}{l}\text { The period is from } \\
\text { irradiation stop to } \\
\text { dismantling }\end{array}$ & $\begin{array}{c}\text { Exposure } \\
\operatorname{dose}^{* 3}(\mu \mathrm{Sv})\end{array}$ \\
\hline \multirow[t]{2}{*}{$\mathrm{A}$} & 2010 & 10 & 7 & D1 & 2 & 3 days & ND \\
\hline & 2010 & 10 & 2 & D2 & 2 & 3 days & 0 \\
\hline \multirow[t]{3}{*}{$\mathrm{B}$} & 2008 & 18 & 10 & D1 & 12 & \multirow{3}{*}{$\begin{array}{c}1 \text { week } \\
\text { (average) }\end{array}$} & ND \\
\hline & 2009 & 15 & 24 & D1 & 34 & & ND \\
\hline & 2010 & 18 & 28 & D1 & 26 & & ND \\
\hline $\mathrm{C}$ & $2007-2010$ & 10 & 60 & D1/D2 & 30 & about 1 week & $\mathrm{ND} / 0$ \\
\hline \multirow[t]{2}{*}{$\mathrm{D}$} & $2008-2010$ & 10 & 7 & D2 & 7 & $\begin{array}{c}2-3 \text { weeks } \\
\text { (average) }\end{array}$ & 0 \\
\hline & 2009 & 14 & 2 & D2 & 1 & 2 weeks & $1 / 0$ \\
\hline
\end{tabular}

*1: These data are provided by accelerator company. And staff only handle accelerator.

*2: D1 is dosimeter for individual exposure and detection limit is $0.1 \mathrm{mSv} / \mathrm{month}$. D2 is pocket dosimeter and detection limit is $1 \mu \mathrm{Sv}$.

*3: ND means non-detect (below the detection limit).

を明らかにした(vii)。また，放射線安全に関する医療 機関からの説明が必要と考えていることも併せて考える と放射化物の種類, 放射能, 線量率および部品等の詳 細や実際の被ばく線量等の情報の共有を進め，保守担 当者や放射線治療装置メーカが減衰期間を判断するた めの環境をさらに整備することで合意形成がさらに前 進する環境が整いつつあると考える。

本研究では， RCによって直接効果があったものもあ る. また，直接の効果はなくても $\mathrm{RC}$ の調査結果におい て特定の回答の割合の大きさや複数の回答を総合的に 検討することで課題の原因を明確にしその改善策に繋 げるという間接的な効果もあった，さらに，本研究を踏 まえ下記の 3-3に示した今後の改善策を実行するととも に医療機関と放射線治療装置メーカの合意形成に向け て具体的なルールの検討あるいは提案が必要な時期に 到達しつつあることがわかった。これらを踏まえるとわ れわれが実施した RCによって解体作業ルールの合意 形成を前進させたことが示唆された。

\section{3-3 得られた結果および知見と改善策}

われわれは本研究によって約 2 力月間の RCにもかか わらず多くの結果と知見を得た (i〜vii)。しかし，短期 間の RC は必ず期待通りに進むとは限らず，また， RC はリスク管理のほんの一部であり， RCが必ずしもより よい決定にいたるとは限らない22, 23) ことを理解しておく 必要がある。

これらを総合的に考えると，解体作業ルールの合意 形成を図る前に関係者すべてが協力して保守担当者と の RC の継続あるいは強化を図ることが重要であると考 える，具体的な実施方策を以下に列挙する。
1)保守担当者が医療機関から放射線安全に関する説明 が必要と考えていること(結果 2-3) および放射化状況に 応じて減衰期間を決めるべきと考えていること(vii)か ら，医療機関が放射線治療装置の放射化状況が推定で きる使用状況(例えば，X線エネルギーごとの使用線 量)を放射線治療装置メーカならびに担当者に情報提供 する体制を整備する。

2)放射線管理区域に扔ける作業での被ばく不安が減少 しなかったこと(結果 2-4) から，保守担当者は複数の医 療機関で作業し，異なる装置を取り扱うことを踏まえ， 可能な限り作業ごとの被ばく線量を計測し保守担当者 と医療機関がその線量情報(検出限界以下を含む)を共 有する。これによって放射化物からの被ばく線量が少 ないことや作業ごとの線量の多寡を保守担当者自身も その場で確認することができ，不安の減少に繋げること ができる。

3)低線量放射線の人体影響をどのように伝えるかが課 題になっていること(vi)から，保守担当者に対して，放 射線治療装置メーカ，医療機関あるいは関連団体等が 低線量被ばく影響について教育訓練を充実させて行う.

4)保守担当者が放射線安全に関する医療機関からの説 明が必要と考えていること(結果 2-3)，また，放射線治 療装置の放射化物に関する本格的な規制整備は始まっ たばかりであり，今後情報量が増加する可能性が高い ことから，放射化物の種類，放射能，線量率および部 品等の詳細を関連団体等が医療機関ならびに保守担当 者に継続して情報提供を行う。

5)本研究では保守担当者に限定した調查であったこと から，もう一方の医療機関側に対しても減衰期間を含む 解体作業ルールについて意識調査を行う。 
6) 保守担当者が放射化状況に応じて減衰期間を決める べきと考えていること (vii) から, 医療機関側の意向も踏 まえたうえで具体的な放射化の状況に応じた解体作業 ルールの検討あるいは提案を行う。

\section{3-4 本研究の新規性と重要性}

放射線治療装置の放射化物に対して小物量であって もクリアランスレベルを適用した放射線安全面を重視し た規制は世界的に見ても本邦が初めての試みである，X 線の最大エネルギーが $10 \mathrm{MeV}$ を超える装置について は, 発生する放射化物の核種, 放射能濃度㧍よび線量 率が示されているが $10 \mathrm{MeV}$ 以下の放射線治療装置に ついては報告がほとんどない24). 放射化物により近い位 置で作業するのは放射線治療装置の保守担当者であり ながら, 報告された管理区域内の線量分布からある程 度推察できるものの明確に測定された報告はない。した がって, 本稿は世界で初めて放射線治療装置の保守担 当者の実被ばく線量を報告した論文である.

また，社会的背景をもつ放射化物対策の課題に対し て, 保守担当者の意識を調査によって捉え, 本研究に よって独自に課題の特性を把握し, 改善策にも繋げると いう本研究の新規性と重要性を示した。

さらに, ルール形成を目指して医療機関の加速器を 扱う作業者を対象に放射化物の放射線管理に関する意 向を RCを伴う介入研究で調べたものは世界的にも例 がない。

\section{4. 結 論}

われわれがブックレットおよび講習会によって実施し た RCにて改正障防法の概要やクリアランス制度ならび に放射化物に対する保守担当者の理解が進んだことが
示唆された，また，保守担当者は作業中受ける線量が 小さいことは理解しており低線量被ばくによる人体影響 の受け止め方が課題であると推察された，装置解体作 業ルールに関しては，放射化状況に応じて検討すべき との回答が多数であった。われわれが実施した RC は 保守担当者側において装置解体作業ルールの合意形成 を前進させたことが示唆された，しかし，ルール合意形 成には医療機関側の意識調査も必要である。さらに, わ れわれは本研究によって独自に課題の特性を把握し, 改善策を明らかにした，そして，本邦の放射線分野の RCに扔ける実践的な先行研究となった。

放射線治療装置の解体作業ルールの合意形成を図る ため, 本研究によって得られた知見を活かし，すべての 関係者が協力して RC を継続するとともに放射化状況 に応じた解体作業ルールの検討あるいは提案を行うこ とが必要である。

\section{謝 辞}

本調査にご協力いただいた放射線治療装置メーカの メンテナンス担当者ならびにメーカ関係者に感謝を申し 上げます。また，ご指導いただいた鈴鹿医療科学大学 大学院 中山良平客員准教授, 土屋 仁教授に感謝申し 上げます。

な挹, 本研究は, JSRT 学術交流委員会関係法令等 検討小委員会・放射線治療分科会, JIRA ならびに合同 WG の支援を受けた。ささらに，本研究の一部はJSRT 第 40 回秋季学術大会(平成 24 年, 東京) および日本放射 線安全管理学会第 11 回学術大会 (平成 24 年, 大阪)に おいて発表した。 


\section{参考文献}

1）保科正夫. 放射線治療用加速器に扔ける放射化一高エネル ギー X 線による光核反応と中性子による核反応一。放射線 治療分科会誌 2010; 24(2): 12-25.

2) 福間宙志, 江口佑太, 磯山 茂, 他. 医用直線加速器装置 の高エネルギーX 線による放射化の解析〜線量測定と被ば く線量の推定〜.日放技学誌 2010; 66(5): 495-501.

3) Beckham WA. Neutron and gamma ray measurements carried out around a Varian Clinac 2500 linear accelerator. Br J Radiol 1990; 63(748): 298-301.

4) 津田政行, 母里知之. $18 \mathrm{MVX}$ 線治療室の誘導放射線によ る被ばく線量の推定. 放線医物理 1995; 15(3): 210-219.

5) Rawlinson JA, Islam MK, Galbraith DM. Dose to radiation therapists from activation at high-energy accelerators used for conventional and intensity-modulated radiation therapy. Med Phys 2002; 29(4): 598-608.

6) Perrin B, Walker A, Mackay R. A model to calculate the induced dose rate around an 18 MV ELEKTA linear accelerator. Phys Med Biol 2003; 48(5): N75-N81.

7) Fischer HW, Tabot B, Poppe B. Comparison of activation products and induced dose rates in different high-energy medical linear accelerators. Health Phys 2008; 94(3): 272278.

8) Almén A, Ahlgren L, Mattsson S. Absorbed dose to technicians due to induced activity in linear accelerators for radiation therapy. Phys Med Biol 1991; 36(6): 815-822.

9) IEC standard 60601-2-1, edition 3, 2009. Medical electrical equipment. Part 2-1: Particular requirements for the basic safety and essential performance of electron accelerators in the range $1 \mathrm{MeV}$ to $50 \mathrm{MeV}$.

10)「放射性廃棄物等の管理と処分に関する研究」班報告書, http://www.jsrt.or.jp/gakujutukenkyuhan/houkoku1_ watanabe.pdf.

11）渡辺 浩, 山口一郎, 藤淵俊王, 他. クリアランス制度等の 法整備の現状と放射線診療関係学会等団体の取り組みにつ いて. 日放技学誌 2010; 66(7): 829-832.

12) Yamaguchi I, Tanaka S, Fujibuchi $T$, et al. Nationwide survey on the operational status of electron accelerators for radiation therapy in Japan. Radiol Phys Technol 2010; 3(2): 98-103.

13）高エネルギー加速器研究機構, 平成 19 年度委託業務成果
報告書(平成 19 年度原子力利用安全対策等委託事業)「小規 模医療用放射線発生装置使用施設におけるクリアランス制 度導入に向けた適切な放射化物の取扱いに関する調査報告 書」, 2008.

14）高エネルギー加速器研究機構, 平成 20 年度委託業務成果 報告書(平成 20 年度原子力利用安全対策等委託事業)「放射 線治療用直線加速装置使用施設及び PET 診断薬製造用サ イクロトロン使用施設等における放射化評価手法並びに放 射化物の発生状況及び取扱いに関する調査」, 2009.

15）高エネルギー加速器研究機構, 平成 21 年度委託業務成果 報告書(平成 21 年度科学技術試験研究委託事業)「放射線発 生装置の使用に伴い生じる放射化物の安全規制に係る技術 基準等に関する調査」, 2010.

16) 渡辺 浩, 藤淵俊王, 山口一郎. 治療用加速器の放射化問 題への対応. 日放技学誌 2011; 67(5): 581-586.

17）柳井久江. 4 Steps エクセル統計第 2 版. 東京 : オーエムエ 又出版, 2009.

18) R Development Core Team (2011). R: A language and environment for statistical computing. R Foundation for Statistical Computing, Vienna, Austria. ISBN 3-900051-07-0, URL http://www.R-project.org/.

19）日本アイソトープ協会 訳. 作業者の放射線防護に対する一 般原則(ICRP Pub.75)。東京：丸善, 1998 .

20）日本アイソトープ協会 訳. 国際放射線防護委員会の 2007 年勧告(ICRP Pub.103)。東京：丸善, 2009.

21) IAEA: SAFETY SERIES No. 115, INTERNATIONAL BASIC SAFETY STANDARDS FOR PROTECTION AGAINST IONIZING RADIATION AND FOR THE SAFETY RADIATION SOURCES, 1996. (VIENNA)

22) National research Council: Improving Risk Communication. National Academy Press (1989)(林 裕造, 関沢 純 監訳. リスクコミュニケーションー前進への提言), 東京： 化学工業日報社, 1997.

23）吉川肇子 編著. 健康リスク・コミュニケーションの手引き. 東京：ナカニシヤ出版社, 2009.

24) Fujibuchi T, Obara S, Yamaguchi I, et al. Induced radioactive nuclides of $10-\mathrm{MeV}$ radiotherapy accelerators detected by using a portable HP-Ge survey meter. Radiat Prot Dosimetry 2012; 148(2): 168-173. 